\title{
EFFECT OF COW AND POULTRY MANURES AS BASAL FERTILIZERS ON MARKETABLE FRUIT YIELD OF OKRA (ABELMOSCHUS ESCULENTUS L)
}

\author{
Viharnaa S and Thayamini H Seran \\ Department of Crop Science, Faculty of Agriculture, Eastern University, Chenkalady, Sri Lanka
}

Accepted: 21 September 2012

\begin{abstract}
An experiment was conducted to study the influence of cow and poultry manures on the marketable yield of okra (Abelmoschus esculentus L) on sandy regosol. The treatments included basal applications of inorganic fertilizer (control) and combined use (10t/ha) of cow plus poultry manures (CM: PM) at ratios of 5:0, 4:1, 3:2, 2:3, 1:4 and 0:5. Significantly higher $(P<0.05)$ marketable yield $(13 t / h a)$ was recorded in plots treated with $C M: P M$ at $3: 2$ ratio as compared to the control $(9 \mathrm{t} / \mathrm{ha})$.
\end{abstract}

Key words: Cattle manure, marketable fruit yield, okra, poultry manure

\section{INTRODUCTION}

Okra (Abelmoschus esculentus L) is one of the most important warm season fruit vegetables grown throughout the tropics and valued for its edible green pods that are popular vegetable in Sri Lanka, ranked fourth in cultivated extent (Anon 2007). Pods are tender bright green and not fibrous (Boelje and Eidman 1984). Okra plays an important role to improve the palatability of many dishes and is generally used as nutritional supplements for vitamin C and A, B complex etc. (Adebooye and Oputa 1996).

Most of the inorganic fertilizers used in conventional agriculture mainly contain NPK and it depletes the available trace minerals from the soil and affects the soil living organisms and human mineral consumption (Reijntes et al. 1992). Application of excess inorganic fertilizer leads to higher pest and disease attacks and also destroys the soil microorganisms. Hence, sustainable farming looks for making the best use of natural resources without damaging the environment and indigenous agricultural knowledge is a vital part of the process of making agriculture sustainable (Ramprasad et al. 2009). The cow and poultry manures are source of plant nutrients and a good depositor of major and minor mineral elements for enhancing soil fertility on application (Thomas 1997). Information pertaining to the combined effect of cow and poultry manures as the basal

*Corresponding author: thayaseran @ yahoo.com fertilizer in okra cultivation is scanty. Therefore, this field experiment was conducted to select the best proportion of cow and poultry manures on marketable fruit yield of okra on sandy regosol.

\section{MATERIALS AND METHODS}

The study was conducted in 2010/2011 at the Eastern region of Sri Lanka ( $81^{\circ} 34^{\prime}$ latitude and longitude $7^{\circ} 48^{\prime}$ ) and at an elevation of $100 \mathrm{~m}$ above MSL. The texture of soil is sandy regosol. The annual mean temperature is $31 \pm 2^{\circ} \mathrm{C}$ and the mean rainfall ranges from 1,800 to $2,100 \mathrm{~mm}$ and the humidity is $60 \%$ $90 \%$. It was carried out in a Randomized Complete Block Design (RCBD) with seven treatments and three replications. The treatments included combined application of cow and poultry manures $(10 \mathrm{t} / \mathrm{ha})$ at the different ratios (CM: PM at 5:0, 4:1, 3:2, 2:3, 1:4 and 0:5) (treatment from $\mathrm{T} 2$ to $\mathrm{T} 7$ ) as a basal fertilizer application and recommended inorganic fertilizer as a control (T1). The plot size was $2.4 \mathrm{~m} \mathrm{x}$ $3.0 \mathrm{~m}$. The air dried cow and poultry manures were collected and then poultry manure was sieved to remove unwanted materials before being used in this experiment.

The required amount of cow and poultry manures according to the ratio was added two weeks before planting to each plot as assigned 
in different treatments, T2-T7 and recommended inorganic fertilizer $(150 \mathrm{~kg} / \mathrm{ha}$ urea, $200 \mathrm{~kg} / \mathrm{ha}$ triple super phosphate and $75 \mathrm{~kg} / \mathrm{ha}$ muriate of potash) was applied two days before planting to T1 plot (control) as basal fertilizer. The okra seeds $c v$ Haritha were soaked overnight and planted at the space of $60 \mathrm{~cm}$ between rows and $60 \mathrm{~cm}$ within rows. Three seeds were placed into each hole and after two weeks of planting, excess seedlings were thinned out in order to maintain two plants per hole. Watering was done twice a day until germination then it was irrigated at alternative days according to the weather condition. Weeding was done manually and 30 days after planting, urea $(150 \mathrm{~kg} / \mathrm{ha})$ and muriate of potash $(75 \mathrm{~kg} / \mathrm{ha})$ were applied as top dressing to all the experimental plots (T1 to T7). No pesticide was used because of less pest attacks.

The length of each marketable fruit was measured at picking and the numbers of fruits per plant were counted. Yield per hectare based on fresh basis were calculated. The data was analyzed using SAS 9.1 version statistical software package. The means were compared by using Duncan's Multiple Range Test at 5\% level.

\section{RESULTS AND DISCUSSION}

There was significant $(\mathrm{P}<0.05)$ difference in length of fruits among the treatments (Table 1). The maximum length of $18.4 \mathrm{~cm}$ was recorded in cow and poultry manures (CM:PM) at 3:2 (T4) and the minimum value of $16.7 \mathrm{~cm}$ was in inorganic fertilizer (T1). This is attributed due to the application of organic manures which may improve soil properties resulting in better supply of macro and micro nutrients for better growth of okra and maintaining soil fertility. The superiority of poultry manure for crop growth has been reported by Wijewardena and Yapa (1999).

The maximum value of $233.9 \mathrm{~g}$ with highest number of cumulative fruits was recorded in T4 (Tables 1\&2) and inorganic treatment (T1) gave relatively lowest fresh weight of fruits (161.2g) with lowest number of cumulative fruits than the other treatments. This result is supported with $\mathrm{Xu}$ et al. (1997) who reported that organic fertilizers promote root growth and activity of sweet corn plants than inorganic fertilizers. Fertilizer is one of the most important inputs contributing to fruit production.

Table 1: The fruit length and number of fruits per plant in each treatment $(\mathrm{N}=3)$

\begin{tabular}{llc} 
Treatment & $\begin{array}{c}\text { Fruit length } \\
(\mathrm{cm})\end{array}$ & $\begin{array}{l}\text { Number of } \\
\text { fruits per plant }\end{array}$ \\
\hline T1 (control) & $16.7 \pm 0.3 \mathrm{~b}$ & $6.8 \pm 0.3 \mathrm{~b}$ \\
T2 & $16.9 \pm 0.4 \mathrm{ab}$ & $7.7 \pm 0.2 \mathrm{a}$ \\
T3 & $17.0 \pm 0.6 \mathrm{ab}$ & $7.8 \pm 0.2 \mathrm{a}$ \\
T4 & $18.4 \pm 0.5 \mathrm{a}$ & $8.5 \pm 0.2 \mathrm{a}$ \\
T5 & $17.2 \pm 0.4 \mathrm{ab}$ & $8.0 \pm 0.3 \mathrm{a}$ \\
T6 & $17.4 \pm 0.7 \mathrm{ab}$ & $7.9 \pm 0.1 \mathrm{a}$ \\
T7 & $17.6 \pm 0.1 \mathrm{ab}$ & $7.8 \pm 0.4 \mathrm{a}$ \\
\hline F test & $*$ & $*$ \\
\hline
\end{tabular}

Generally the plant having a better system can absorb more water and support for photosynthesis. Addition of both cow and poultry manures to soil causes to increase soil organic matter content that has the capacity to improve water holding capacity and retain nutrients for a longer period. On the contrary, inorganic fertilizers release nutrients quickly and it remains for a short period and excess nutrients may leach out especially on sandy soil. Several workers have been reported longer residual effect of organic manures when apply to the soil (Adeniyan and Ojeniyi 2003).

Table 2: The fresh weights of cumulative marketable fruits in each treatment $(\mathrm{N}=3)$

\begin{tabular}{lll}
\hline Treatment & $\begin{array}{l}\text { Fruit weight }(\mathrm{g}) \\
\text { per plant }\end{array}$ & $\begin{array}{l}\text { Fruit yield } \\
\text { t/ha }\end{array}$ \\
\hline T1 (control) & $161.2 \pm 9.9 \mathrm{~d}$ & $09.0 \mathrm{~d}$ \\
$\mathrm{~T} 2$ & $173.1 \pm 8.7 \mathrm{~cd}$ & $09.6 \mathrm{~cd}$ \\
$\mathrm{~T} 3$ & $194.8 \pm 6.3 \mathrm{bc}$ & $10.8 \mathrm{bc}$ \\
$\mathrm{T} 4$ & $233.9 \pm 5.0 \mathrm{a}$ & $13.0 \mathrm{a}$ \\
$\mathrm{T} 5$ & $202.1 \pm 8.0 \mathrm{~b}$ & $11.2 \mathrm{~b}$ \\
$\mathrm{~T} 6$ & $200.9 \pm 8.9 \mathrm{~b}$ & $11.2 \mathrm{~b}$ \\
$\mathrm{~T} 7$ & $211.3 \pm 7.5 \mathrm{~b}$ & $11.7 \mathrm{~b}$ \\
\hline F test & $*$ & $*$
\end{tabular}

The present results indicated that the cow and poultry manures at the ratio of $3: 2$ applied as basal fertilizer (T4) gave high yield of 13t/ha followed by $\mathrm{T} 7(11.7 \mathrm{t} / \mathrm{ha})$ but there was re- 
markable $(\mathrm{P}<0.05)$ variation between them. The reason may be due to incorporation of poultry manure which contains high NPK content (Waddington 1998). However, it leads to increase acidity in the soil. Kiyonori (1990) reported that the low $\mathrm{C} / \mathrm{N}$ ratio of poultry litter results in the loss of nitrogen through ammonia volatilization. This causes nutrient imbalance in the crop and also reduction in the uptake of certain nutrients (Ewulo et al. 2008). The increase application of cow manure leads to increase the rate of photosynthesis (Sanwal et al. 2007). Hence, proper amount of good organic manures are required to supply the nutrients for crop growth and development. Ayoola and Adeniyan (2006) reported that nutrient from mineral fertilizers enhance the establishment of crop while organic manure promotes yield when both fertilizers were combined. The combined use of organic manure and inorganic fertilizer could narrow down the negative nutrient balance substantially in many cropping systems (Singh and Yadav 1994).

\section{CONCLUSION}

Application of cow and poultry manures (CM: $\mathrm{PM})$ at 3:2 ratio significantly increased marketable fruit yield (13t/ha) of okra as compared with the other ratios (CM: PM at 5:0, $4: 1,2: 3,1: 4$ and 0:5) and inorganic fertilizer applied as basal application on sandy regosol.

\section{REFERENCES}

Adebooye OC and Oputa CO 1996 Effects of galex on growth and fruit nutrient composition of okra (Abelnurschus esculentus). Ife J. Agric. 18 (1\&2): 1-9.

Adeniyan ON and Ojeniyi SO 2003 Comparative effectiveness of different levels of poultry manure with NPK fertilizer on residual soil fertility, nutrient uptake and yield of maize. Moor J. Agric. Res. 4 (2): 191-197.

Anon. 2007 AgStat Socio Economic and Planning Centre, Department of Agriculture, Sri Lanka.

Ayoola OT and Adeniyan ON 2006 Influence of poultry manure and NPK fertilizer on yield and yield components of crops under different cropping systems in south west Nigeria. African J. Biotech. 5 (15):1386-1392.

Boelje MD and Eidman VR 1984 Farm management. John Wiley and Sons, New York, USA.

Ewulo BS, Ojeniyi OS and Akkani DA 2008 Effect of poultry manure on selected soil physical and chemical properties, growth, yield and nutrient status of tomato. African J. Agric. Res. 3: 612616.

Kiyonori H 1990 Production of compost from organic wastes. Food and Fertilizer Technology Centre. Extension Bulletin No. 311.

Ojeniyi SO, Owolabi O, Akinola OM and Odedina SA 2009 Field study of effect of organomineral fertilizer on maize growth yield soil and plant nutrient composition in Ilesa, southwest Nigeria. Nigeria J. Soil Sci. 19: 11-16.

Sanwal SKK, Lakminarayana RK, Yadav N, Rai DS, Yadav and Mousumi B 2007 Effect of organic manures on soil fertility, growth, physiology, yield and quality of turmeric. Indian J. Hort. 64(4): 444-449.

Singh GB and Yadav DV 1994 Critical analysis of the long term manorial experiments on sugarcane in India. Fertilizer News 39(10): 25-34.

Thomas GA 1997 Toxicity identification of poultry litter aqueous leachate. Soil Fertilizer 8(61): 251-252.

Ramprasad V, Srikanthamurthy HS, Ningappa, Shivakumar, Nagaraju,B., Ningaraju, Shashidhara, Doddappa, Vijay AR, Shivanna M, Obanna N, Pandu AC, Rama S, Sundhya M, Veena P and Suma S 2009. A Handbook on Sustainable Agricultural Practices, Fist edition, Green Foundation, Bangalore.

Reijntjes C, Haverkort B and Water-Bayer A 1992 Farming for the Future. An Introduction to Low-external Input and Sustainable Agriculture. Macmillan Press, London.

Waddington SR 1998 Organic matter management: From Science to Practice. Soil Fertilizer 3(62): 24-25.

Wijewardena JDH and Yapa UWSP 1999 Effect of combined use of animal manure and chemical fertilizer on potato and vegetable cultivation in upcountry of Sri Lanka. Sri Lankan J. Agric. Sci. 136: 68-82.

Xu, H. L., Kato, S. Yamada, K.,Fujita, M. and Katase, K. (1997). Soil root interface water potential in sweet corn plants affected by organic fertilization and effective microbes application. Jap. J. Crop Sci. 66: 110-111. 